\title{
A fragility approach to campus sustainability - methodological explorations
}

\author{
Author: Johannes Platje
}

\begin{abstract}
Aim: Often, the approach towards entering a path of sustainable development is that intervention needs to take place. This may lead to unwanted side effects. This paper presents ideas for explorative research on campus sustainability. The aim is to create a basis for developing a methodology for identifying fragilities, threats to organizational viability and sustainable development of the external environment.

Design / Research methods: The ideas presented in this paper were developed through literature study and discussed during three explorative research workshops organized in May and June 2016 at the WSB University in Wrocław (Poland), the University of Sonora (Hermosillo, Mexico) and Siauliai University (Lithuania). The ideas developed are the basis for future research on the issue.

Conclusions / findings: The category mistakes, together with issues of the organization's cognitive capacity as well as governance, can show the capacity of universities to identify and deal with unsustainable practices and fragilities that may threaten its viability. The survey presented and discussed in reflection papers in this volume will be the base for further research on how to improve campus sustainability by eliminating unsustainabilities.

Originality / value of the article: While the traditional approach towards campus sustainability is what action should be undertaken in order to support this aim, in this paper focus is on what not to do. It can be expected that this approach leads to less undesired side-effects than an interventionist approach
\end{abstract}

Keywords: campus sustainability, sustainability management, fragility, History: received 2016-11-30, methodology corrected 2016-12-05, accepted JEL: Q01, B40, 123 2016-12-05 


\section{Introduction}

The contribution of institutions of higher education to sustainable development has become a field of increasing importance in the discourse on sustainable development (e.g. Thomas, Depasquale 2016). The issue is not only whether an institution of higher education itself contributes to sustainability by, for example, increasing energy efficiency, proper waste management, procurement of sustainable products, etc. (Sintov et al. 2016), but also whether it has a positive influence on the social, environmental and economic sustainability of the external environment (Platje 2015). The approach towards so-called campus sustainability seems often to be based on the idea, which also can be found in business, that activity has to be undertaken to improve the situation. In other words, what should be done in order to create a more sustainable campus and a more sustainable society. While reading Nassim Taleb's Antifragile (2012), the idea appeared to look at campus sustainability from an opposite perspective: what not to do in order to achieve an improvement (Platje 2015a).

Important for processes supporting campus viability and sustainability are learning processes and learning-by-doing. Or better, learning what not to do. The capacity for creating such knowledge, about what not to do in order to prevent threats to the existence of the organization and/or its external environment, may be the bottom-line of campus sustainability.

As this is a relatively new approach towards campus sustainability, first a methodological basis needs to be established. The aim of this article is to present ideas regarding the development of indicators of campus unsustainability. These ideas were developed through literature study and discussed during three explorative research workshops organized in May and June 2016 at the WSB University in Wrocław (Poland), the University of Sonora (Hermosillo, Mexico) and Siauliai University (Lithuania). Reflection papers of participants of the three workshops can be found in the rest of this special volume of the WSB University in Wrocław Research Journal. The ideas developed are the basis for future research on the issue.

The article is structured as follows. First, the general background of the explorative workshops is provided. Then, the theoretical background regarding notions and theories behind the development of questions elaborated at the workshop is presented. After the discussion of the questionnaire as well as outcomes of the workshops, conclusions will be drawn.

\section{General background}

The general aim of the explorative research workshop was to discuss and exchange opinions regarding the contribution of universities to sustainable development. This should be a starting point for achieving the following specific aims by way of deeper research in the future:

- Develop indicators measuring organizational fragility.

- Develop indicators measuring the fragilization of society by way of an organization's functioning.

- Create such a set of indicators making an international comparison of universities functioning in a different institutional setting possible.

- The indicators should enable the application of subtractive epistemology - eliminate what makes an organization or its external environment fragile.

The focus was on identifying fragilities - weaknesses in the organization or the system, that can lead to irreversible losses. This is in particular important in complex and tightly knit 
systems, where fragilities, bottlenecks, etc. can lead to chain effects with unpredictable, irreversible and nonlinear damage due to the strong interconnectedness (Perrow 1999, Harford 2011, Taleb 2012).

In the discussion on campus sustainability and fragility, the following issues were considered:

- The university as such is a complex system. However, it is not such a tightly knit system, that a break down somewhere in the organization will quickly lead to collapse. In this context, fragilities need to be identified that threaten the functioning of the university, but maybe more important, activities that fragilize the external environment, and/or negatively influence local sustainable development. In particular indicators should be developed showing the organization's capacity to enable such identification of fragilities, learn from mistakes and the ability to support sustainability by elimination of, for example, bad practice instead of undertaking interventive action.

- During the workshop, the relevance of different indicators and statements for identifying fragilities were discussed. These indicators and statements were developed based on theoretical considerations (a general outline is presented below) as well as the questionnaires filled out by all the participants in the preparation phase of the workshop.

The workshop held in May 2016 in Wrocław (Poland) was divided into three sessions The first session, for which 90 minutes was planned, was structured as follows.

a. All participants individually filled out a questionnaire where they had to assess to what extent they disagree or agree with statements in the context of their impression of their own home university. b. Then they assessed whether they consider indicators to be relevant or irrelevant for the identification of fragilities.

c. The indicators assessed as relevant had then to be assessed on the seriousness and likeliness of threats for the organizational viability or the university as well as the sustainability of the external environment. Focus was on challenges and threats, as the assumption is that the bottom-line of viability and sustainability is survival (lack of irreversible damage that increase the probability of collapse scenarios). While opportunities are for improving viability and sustainability are relevant, they were not considered in this research due to the specific methodological approach - look at what can be eliminated in order to improve viability and sustainability.

The following general definitions were emphasized, that the participants should keep in mind during the workshop.

- Organizational viability - the organization can function and develop without creating weaknesses and fragilities threatening its long-term existence.

- Sustainability of the external environment - to what extent can an action of the organization related to the indicator/statement have a negative impact on the rest of society.

The second session (90 minutes) started after a 30 minutes break. The participants were divided into focus groups. The aim of the discussions in the focus groups was:

a. To assess the indicators the individual participants considered to be irrelevant, and exchange opinions on this issue. Discussion could concern the correctness of decisions on irrelevancy of statements, but also focus on developing new ideas. 
b. To discuss the importance of the indicators that were considered to be relevant, and discuss whether something should be added. In particular this should concern the indicators of phenomena that may cause irreversible damage to organizational viability and/or the sustainability of the external environment.

The third session (90 minutes) was an open discussion with all participants on the results of the focus group discussion, and reflection on the possibility of using the indicators and statements discussed for an international comparative study on campus viability and sustainability.

The workshops in Siauliai (Lithuania, 12 students and 6 lecturers engaged in studies on sustainable business) and Hermosillo (Mexico, 19 students and 7 staff members engaged in a post-graduate sustainability certificate course) were organized along similar lines as the Wrocław workshop. In the Wrocław workshop, a mixed group of students and staff from a wide range of countries took part (24 Participants from Poland, Germany, The Netherlands, Mexico, Lithuania, Kazakhstan, Turkey -12 lecturers and 12 students). The participants of the workshops received in advance some theoretical background (described below) in order to get acquainted with the ideas behind the workshop. This should lead to a better understanding of the reasons behind the questions in the questionnaire, and make the participants better prepared for a critical discussion. The discussion had an open character, where the organizers did not intervene in the process.

\section{Some theoretical background - notions and theories behind the development of indicators}

When assessing fragilities threatening organizational viability and/ or the sustainability of the external environment, the following issues should be kept in mind. The bottom line of viability and sustainability is survival. In this context, the aim of science is to eliminate lies, nonsense, threats to human existence, etc. It is about eliminating mistakes and problems that can destroy us, as well as enabling people, organizations and society to deal with such mistakes and problems when they cannot be prevented. This means a change in the approach as the world is too complex to engineer top-down. If we undertake policy, we should know what not to do. This is related to the idea that truth is difficult to establish (lack of information in complex systems), and policy outcome is difficult or impossible to predict due to complexity related to many potential side effects (see Kahneman 2011, Taleb 2012). Furthermore, what is good is probably more normative than what is bad, and it tends to be more difficult to obtain agreement on what is good than what is bad (Taleb 2012).

This approach requires a change in the way people think as well as worldviews (mental models), as well as organizational and societal goals - it is not about bringing us into heaven, but keeping us out of hell. ${ }^{1} \mathrm{~A}$ Leitmotiv of the approach is: "The road to heaven may be worse than hell." So, the basic idea is that it is better not to interfere with small everyday peoples' issues. Let them try and error as this is a source of direct knowledge. However, be precautious about large scale top-down experiments as well as topdown intervention and regulation, as this tends to have more negative effects than leaving people free choice.

\footnotetext{
1 This is a paraphrase from Dag Hammarskjöld, the Secretary-General of the United Nations from 1953 to 1961, who said "The UN was not created to take mankind to heaven, but to save humanity from hell." (https://en.wikipedia.org/wiki/ Portal:United_Nations/Selected_quote).
} 
It is not about choosing a second-best or optimal solution, but a least bad/ evil or not the worst situation. So, it is not only about creating safeguards, buffers, etc. in order to reduce unsustainability (and manage negative Black Swans, discussed below). It also concerns the acceptance that the priority should be survival of a system in order to obtain a kind of sustainability, while individual mortality is a requirement for system sustainability. This brings about the problem that individual casualties are directly visible and immediately become stories for people giving them incentives to try to eliminate these casualties (compare Kahneman 2011). Top-down intervention often leads to "unexpected side effects" (Sterman 2000) where costs are often not considered as they are indirect, long-term, uncertain, nonlinear and difficult to measure (Kahneman 2011, Taleb 2012, Platje 2011). As mentioned, the bottom-line of sustainability is to prevent complete system collapse. One approach to this is the so-called Black Swan Strategy (Taleb 2007, 2012). Preventing the negative Black Swans to appear, or be ready to deal with them, and create options to catch the positive Black Swan.

A negative Black Swan is a low probability and often unexpected event that leads to irreversible destruction. An example is related to the development of the Internet and the strong reliance on IT. Access to the Internet replaces traditional libraries, changes traditional ways of administering universities, etc. The moment that the Internet would break down due to one or the other reason, society may break down (see Casti 2013). Internet and IT has brought huge developmental advantages and efficiency gains in many types of business, but society in probably most of the countries in the world is so dependent on it, that without the Internet and IT incredible problems will appear.
Another example concerns the lack of students or good lecturers. While the effects of a demographic boom or decline on the number of students can be predicted, it is more difficult to foresee the demand for individual study programmes. Here, the question appears whether universities are prepared for such phenomena. Do they have the resources available to find new students, start new study programmes, find new sources of funding, etc.? While as such not being a Black Swan, when following the logic of Taleb (2007), they are a Black Swan for those who fail to foresee the possibility of such developments. When an organization lacks cognitive capacity (Alvesson and Spicer 2012), i.e., reflectivity, justification and substantive reasoning, it seems to be more likely that such negative Black Swans appear.

Generally speaking, slack, redundancy and buffers are instruments to deal with negative Black Swans. While contradicting more traditional approaches to efficiency, it is a low cost strategy to prevent collapse. This can be compared to system theory (Meadows 1998, 1999, Sterman 2000), where positive feedback loops create non-linear dynamic effects that can bring a system out of balance. Reducing slack, redundancy and buffers may lead to small benefits, with the threat of irreversible destruction due to a weakening in an organization or system. Organizations may reduce the threat of negative Black Swans by transferring risks and threats to other stakeholders, in this way fragilizing the system in which they function in the environmental, social and/or economic sphere, in turn contributing to unsustainable development.

A positive Black Swan is a low probability and often unexpected event that leads to very dynamic positive effects for an organization. This element of a Black Swan Strategy relies on creating a wide range of options in order "to be 
there" when, for example, a technological breakthrough takes place. An example is companies that invested in different countries of the former Socialist bloc, in order to be there when a dynamic development would take place. Another example is companies that invest little amounts of money in a wide range of risky ventures. While the loss may be likely, these losses are small and do not threaten the existence of the company. But when one of the investments works out, this may be the Goose with the Golden Eggs. A theoretical problem is that this strategy focuses on innovations that may bring serious gains to an organization. However, these innovations as such may cause serious negative effects, for example regarding the use of natural resources or may replace manual labour, creating structural unemployment for the less educated. This focus on technological advance may lead to permanent exclusion of low educated manual labourers from the labour market, as new jobs appearing can, for example, be robotized (Gates 2014).

When analyzing the positive and negative Black Swans, the use of system theory is required. Positive feedback loops may be triggered by fragilities that can lead the system to get out of control, and finally collapse. Another concept, an institutional equilibrium (where informal rules, including mental models and worldviews, support the formal rules of a system (see Platje 2008)) can be used for analysis of the capability and willingness to think critically, be open minded, etc. This can be connected with the concept organizational stupidity (Alvesson and Spicer 2012), which embraces the three mentioned aspects of cognitive capacity: reflectivity, justification and substantive reasoning. The following hypotheses are considered for the research: a. Lack of cognitive capacity leads to reduced viability of organizations. b. Lack of cognitive capacity leads to fragilizing behaviour of organizations which contributes to the unsustainability of society.

\section{The questionnaire and some results}

The questionnaire discussed at the workshops was the basis for the discussion (for the questions, see the Annex). The questions were developed based on the theoretical ideas discussed earlier, as well as open questionnaires carried out among some scholars and students from Poland, Germany, Mexico and Denmark. As the groups of participants were small and diversified, the answers as such cannot be analyzed in detail when aiming at drawing conclusions. This was not the intention of the questionnaire. The aim was to create a basis for discussion, as well as the reflection papers published in this special issue. These discussions and reflections can be helpful for developing a shorter questionnaire. The questions concerned the following categories: knowledge and education, mistakes and learning-by-doing, governance, different types of fragilities, honesty and trust and the job market. Regarding knowledge and education, the main issue is whether there is focus on knowledge creation or not. When focus is on knowledge creation, it this knowledge creation focused on sustainable development? Mistakes and learning-by-doing embrace learning processes enabling the elimination of mistakes, as well as finding new solutions for problems. It is also an element of creating knowledge, and as such related to the category "knowledge and education." The aim of the questions about governance is to obtain a picture of the strength of the organization to deal with different problems, and in combination with questions asked in the category "mistakes and learning-by-doing" a picture of the level of cognitive capacity of the 
organization. The questions on different types of fragilities aim at finding out whether there are weak links in the university organization that can lead to a crisis, as well as some information on the university's impact on the sustainability of the external environment. Honesty and trust is related to the problem of lying and cheating, which reduces organizational viability as well as the probability of having a positive impact on the sustainability of development (the impact may rather be the other way round). Finally, the questions about the job market focus on the issue whether knowledge is required for finding and keeping a job. This is important for internal incentives for students to study and obtain knowledge.

The answers to the questions and the discussion showed a few important things to be considered for further development of indicators of organizational fragility and the capacity to deal with such fragilities as well as to eliminate different negative impacts on the external environment. In order to obtain a good picture of fragilities and the university's capacity to deal with sustainability issues, students may be a limited source of information on, in particular, governance issues. The research on fragilities should include all internal university stakeholders (administration, lecturers, students, management) who can shed a light on different types of fragilities and may possess different levels of information on specific issues.

It may be a good idea to analyze outliers in the answers. The statements in the questionnaire could be assessed from 7 (strongly agree) to 1 (strongly disagree), while the option "don't know" was given. Complete agreement or disagreement may be, for example, based on knowledge, strong opinions, over-optimism about something or blindness to certain problems. An in-depth interview with these people could possible lead to more information about potential fragilities. However, in this case the problem of lack of anonymousness appears, likely to reduce the response rate while negatively influencing the honesty of answers.

In particular, an interesting category for analysis, besides the mentioned extremes, is the answer "don't know". There are issues which are difficult to assess for stakeholders, like the internal functioning of university management for new students or workers. When such a groups of stakeholders expresses strong opinions about issues they probably do not possess much knowledge about, this requires serious deeper research. Also, strongly differing opinions among different stakeholders about issues like mistakes and governance can be a sign that serious fragilities exist in these areas.

\section{Concluding remarks}

While the task during the workshops was to identify what was not really important and could be eliminated, focus remained on what is important and what action to undertake to support sustainability. This according to the idea that most issues are important, but some are more important than others. Furthermore, multiple interpretations of the meaning of potential indicators lead to discussion on the level of negative impacts of different phenomena, like lying.

Deeper research on a set of indicators regarding campus sustainability is required. The question needs to be addressed whether it will be possible at all to create such a set of indicators that makes international comparison of universities possible. A well-known issue is that the institutional and physical environment in which universities function differ. Regarding outcome indicators presenting the impact 
on, for example, transport sustainability, it will be difficult to compare a university in cities relying mainly on road transport (like Hermosillo) with a city where public transport is pretty well developed (Wrocław). These cities will be difficult to compare with Amsterdam, known for the large amounts of cyclists. Universities also use different resources and face different climatic conditions, influencing their resource intensity. Maybe a starting point for comparison is at the organizational

\section{Bibliography}

Alvesson M., Spicer A. (2012), A stupidity-based theory of organizations, "Journal of Management Studies", vol. 49, no. 7, pp. 1186-1220.

Casti J.L. (2013), X-Events - Complexity overload and the collapse of everything, Harper Collins Publishers, New York.

Gates B. (2014), Bill Gates: People don't realize how many jobs will soon be replaced by software bots, "Business Insider", no. 13 March 2014, http://www.businessinsider. com/bill-gates-bots-are-taking-awayjobs-2014-3 [12.09.2016].

Harford T. (2011), Adapt - why success always starts with failure, Little, Brown, London.

Kahneman D. (2011), Thinking, fast and slow, Penguin Books, London.

Meadows D. (1998), Indicators and information systems for sustainable development, The Sustainability Institute, Hartland.

Meadows D. (1999), Leverage Points - places to intervene in a system, The Sustainability Institute, Hartland. level, identifying the organization's cognitive capacity. Putting it very simply, this concerns the capacity to learn from mistakes, identify and deal with current problems as well as potential negative Black Swans. The category mistakes, together with issues of the organization's cognitive capacity as well as governance, can show the capacity of universities to identify and deal with unsustainable practices and fragilities that may threaten its viability.

Perrow, C. (1999), Normal Accidents, Princeton University Press, Princeton .

Platje J. (2008), ““'Institutional Capital” as a factor of sustainable development - the importance of an institutional equilibrium, "Baltic Journal on Sustainability", vol. 14 , no. 2 , pp. 144-150.

Platje J. (2011), Institutional Capital creating capacity and capabilities for sustainable development, Wydawnictwo Universytetu Opolskiego, Opole.

Platje J. (2015), Beyond resilience new institutional economics, fragilities and indicators of unsustainability, "Central and Eastern European Journal of Management and Economics", vol. 3, no. 4, pp. 295-315.

Platje J. (2015a), Sustainability and antifragility, "Economic and Environmental Studies", vol.15, no. 4, pp. 469-177.

Taleb N.M. (2007), The Black Swan the impact of the highly improbable, Penguin Books, London.

Taleb N.M. (2012), Antifragile - things that gain from disorder, Penguin Books, London. 
Thomas I., Depasquale J. (2016), Connecting curriculum, capabilities and careers, "International Journal of Sustainability in Higher Education", vol. 17 , no. 6 , pp. $738-755$.

Sintov N., Dux E., Tran A. , Orosz M. (2016), What goes on behind closed doors?: How college dormitory residents change to save energy during a competition-based energy reduction intervention, "International Journal of Sustainability in Higher Education", vol. 17 , no. 4 , pp. $451-470$.

Sterman J.D. (2000), Business dynamics: system thinking and modelling for a complex world, Irwin / McGraw Hill, Boston.

\section{ANNEX - THE QUESTIONNAIRE}

Part 1. Please individually fill out the questionnaire and assess to what extent they disagree or agree with statements in the context of their impression of your own home university.

Please assess to what extent you agree or disagree with the following statements. Assess from 7 (strongly agree) to 1 (strongly disagree). ${ }^{2}$

\section{Knowledge and education}

1. The world increases in complexity so fast, that increase in knowledge cannot keep up.

2. It can be very costly to speak the truth at your university.

3. Creating knowledge is less important at our university than obtaining a diploma.

4. In teaching system approaches are hardly used.

5. Knowledge can be obtained when reading summaries of scientific articles.

6. Teaching staff considers websites to be a reliable scientific resource.

7. Teaching staff considers the Internet to be a reliable source of information.

8. The study programme is very business oriented.

9. The study programme is very labour-market oriented.

10. The study programme is focused on environmental protection.

11. The study programme is focused on sustainable production and consumption.

12. I haven't got the slightest idea what sustainable development means.

\section{Mistakes and learning-by-doing}

13. Critique from students / teachers is ignored by the university management.

14. Students at our university ask a lot of questions during classes.

15. Teachers at our university appreciate students asking questions during classes.

16. At our university mistakes are considered a deviation that should be punished.

17. There is hardly any information available about mistakes made by the university authorities.

18. The majority of our lecturers classes are less useful than reading the textbook. 19. At my university, it is better not to make a mistake, as at least it leads to inconveniences with the boss / teacher.

$\overline{2}$ Also the option „don't know” was provided. 
20. When making a mistake, people often get angry at our university.

21. A failure in a research project financed by the government can lead to lack of funding in the future.

22. We do not talk about mistakes at our university.

23. When making a mistake at our university, in general there is a positive atmosphere to find a solution.

24. Mistakes can be made because rules at the university are flexibly enforced.

\section{Governance}

25. There is a lot of secrecy at our university.

26. It is possible to doubt / criticize about management ideas / decisions at our university.

27. There are many closed networks of family and friends at our university.

28 . Changes in the rules at our university are openly discussed.

29. It is common that questions are asked and discussions take place during meetings with the university authorities.

30. There is a large group of "untouchables" at our university.

31. The university authorities and decision makers often provide reasons and explanations for their decisions.

32. Labour unions have a lot of influence at our university.

33. The employment of lecturers depends on relations with family and/or friends.

34. There is a small powerful group at our university that heavily influences policy.

35. There is a lack of access to information at my university.

36. There is a huge political pressure on the selection of the rector, deans etc.

37. At our university there is much corruption.

38. There are a lot of conflicts at my university.

39. There are different strong groups struggling and quarreling at our university.

40. The flow of information between workers at our University is a mess.

41. Organizationally, our university is functioning very well.

42. In general, there are too many changes at our University, and too little time to introduce and manage these changes.

43. The management style of our University is authoritarian.

44. The organizational structure of our university is very centralized.

\section{Different types of fragilities}

45. Firing the least capable half of the professors would certainly improve the quality of research at our university.

46. Firing the least capable half of the academic teachers would certainly improve the quality of teaching at our university.

47. Our university has a negative impact on sustainable development.

48. Our university has a negative impact on urban development.

49. There are a few professors and/or academic teachers without whom the quality of education would drop significantly.

50, There are a few professors and/or academic teacher whose leaving would significantly improve the quality of teaching.

51. If all our teaching staff would leave, and be replaced by other teachers/lecturers, this would not lead to a deterioration of the quality of teaching.

52. There are too few parking lots at my university.

53. There is a huge political pressure on the contents of the study programme.

54 . Things are so bad at our university, that it cannot get worse.

55 . Science at our university contributes to sustainable development. 
56. There is a lot of administrative support for developing grants for funding of research projects.

57. Our university is very heavily dependent of a few people obtaining most of the external financial resources / grants.

58. Informational problems in combination with the complexity of our University organization can lead to a serious threat to the existence or functioning of our University in the future.

59. Our IT personnel can be easily replaced at our University.

60. Our IT personnel is crucial for the functioning of our university.

61. Our University tries to reduce the cost of teaching too much (less teaching hours, employment of free lancers, etc.).

62. There is a lack of knowledge of foreign languages among supporting staff (e.g. security workers) and technical staff, which creates danger for foreign students in case of an emergency.

\section{Honesty and trust}

63. Lecturers at our university are in general honest.

64. Professors at our university are in general honest.

65. Administrative workers at our university are in general honest.

66. University management (rectors, deans) at our university is in general honest.

67. People are in general honest.

68. At our university, people in general do not cheat.

69. At our university teachers seldom or never sell good marks for money to students.

\section{Job market}

70. Contacts are more important than knowledge to find a job after studies.

71. Without knowledge and skills, one can keep a job when having the right connections.

72. For students, in order to enter the labour market (find a job) connections and acquaintances are much more important than knowledge.

73. In order to keep a job, knowledge is very important.

74. In order to keep a job, critical thinking is very important.

75. Employers often headhunt students at our university while still studying.

76. Critical thinking is appreciated by employers in my country.

Part 2. Please assess whether you consider the following indicators to be relevant or irrelevant for the identification of fragilities. Please assess the indicators you think are relevant on the seriousness and likeliness (probability) of potential threats related to the indicators for the organizational viability of the university as well as the sustainability of the external environment. Please assess seriousness and likeliness with $\mathrm{H}$ (high) or L (low).

The following indicators were assessed:

1. Lack of knowledge.

2. Hiding the truth.

3. Lack of critical discussion.

4. Lack of openness to critique.

5. High level of secrecy.

6. Existence of closed networks of family and friends.

7. Ignorance of critique by university management.

8. Students not questioning teachers during classes. 
9. Lack of discussion among university authorities.

10. Existence of strong interest groups.

11. Lack of explanation of decisions by the university management.

12. Lack of system approach in teaching.

13. Punishing people for minor, relatively harmless mistakes.

14. Hiring bad teachers.

15. Lack of honesty.

16. Lack of information on mistakes made.

17. Dependency on a few very good lecturers.

18. Dependency on a few very good scientists.

19. Employment of family and friends.

20. Low quality of teaching staff.

21. Low quality of administrative staff.

22. Lack of high class IT personnel.

23. Lack of use of scientific resources for scientific papers and publications.

24. Corruption.

25. Lack of understanding of sustainable development.

26. Making mistakes.

27. Lack of access to information.

28. Political influence on employment of lecturers and administration.

29. Lack of labour market oriented studies.

30. Lack of environmental elements in the study programme.

31. Lack of social elements in the study programme.

32. Lying and cheating.

33. Conflicts between internal university stakeholders.

34. Lack of parking space for students and staff.

35. Lack of scientific research on sustainable development.

36. Lack of administrative support for developing grant proposals.

37. Lack of discussion about mistakes made.

38. Management focus on cost reduction.

39. Authoritarian management style.

40. Lack of knowledge of foreign languages among university staff and administration.

41. Lack of proper energy management.

42. Lack of proper labour conditions for university staff.

43. Lack of proper education for students.

44. Lack of proper waste management.

45. Lack of facilities for the physically challenged.

46. Employment of many free-lance teachers.

47. Too quick changes in rules, procedures, etc.

48. Lack of trust.

Oparte na kruchości podejście do zrównoważonego rozwoju kampusów rozważania metodologiczne
Abstrakt
Cel: Niejednokrotnie dążenia do wkroczenia na ścieżkę zrównoważonego roz- woju wymagają interwencji, co może prowadzić do niepożądanych efektów ubocznych. Niniejszy artykuł przedstawia idee dotyczące poszukiwawczych badań nad zrównoważonego rozwoju kampusów. Celem jest stworzenie 
podstaw rozwoju metodologii pozwalającej na identyfikację kruchości, zagrożeń wydolności organizacyjnej oraz zrównoważonego rozwoju środowiska zewnętrznego.

Układ / Metody badawcze: Idee zaprezentowane w artykule opracowano na podstawie przeglądu literatury oraz dyskusji podczas trzech warsztatów badawczych, zorganizowanych w maju i czerwcu na WSB we Wrocławiu (Polska), na Uniwersytecie w Sonorze (Hermosillo, Meksyk), a także na Uniwersytecie Szawelskim (Litwa). Idee te stanowią podstawę przyszłych badań nad analizowanymi zagadnieniami.

Wnioski / wyniki: Kategorie błędów, wraz z kwestiami zdolności poznawczej organizacji oraz współrządzenia, mogą ukazać zdolność organizacji do identyfikacji i radzenia sobie z niezrównoważonymi praktykami i kruchościami mogącymi zagrozić jej wydolności. Ankieta przedstawiona i omówiona w zawierających przemyślenia artykułach opublikowanych w tym tomie będzie podstawą dalszych badań nad wzmocnieniem zrównoważonego rozwoju kampusów poprzez wyeliminowanie niezrównoważonych aspektów.

Oryginalność / wartość artykułu: Tradycyjne podejście do zrównoważonego rozwoju kampusu opiera się na działaniach, jakie należy podjąć, aby osiągnąć zamierzony cel. Natomiast niniejszy artykuł wskazuje, czego nie należy robić. Można oczekiwać, że podejście to przyniesie mniej niepożądanych efektów ubocznych aniżeli podejście oparte na interwencjonizmie.

Słowa kluczowe: zrównoważony rozwój kampusu, zarządzanie zrównoważonego rozwoju, kruchość, metodologia 
